\title{
The Different Expressions of Draft Cherry Tomato Growth, Yield, Quality under Bamboo and Rice Husk Biochars Application to Clay Loamy Soil
}

\author{
Tran Thi Thu Hien ${ }^{1,2}$, Yoshiyuki Shinogi1, Tomoyuki Taniguchi ${ }^{*}$ \\ ${ }^{1}$ Laboratory of Irrigation and Water Management, Department of Bioproduction Environmental Sciences, \\ Faculty of Agriculture, Kyushu University, Fukuoka, Japan \\ ${ }^{2}$ Agricultural Science Institute of Northern Central Vietnam, Vinh City, Viet Nam \\ Email: ^taniguchi@bpes.kyushu-u.ac.jp
}

How to cite this paper: Hien, T.T.T., Shinogi, Y. and Taniguchi, T. (2017) The Different Expressions of Draft Cherry Tomato Growth, Yield, Quality under Bamboo and Rice Husk Biochars Application to Clay Loamy Soil. Agricultural Sciences, 8, 934-948.

https://doi.org/10.4236/as.2017.89068

Received: July 24, 2017

Accepted: August 31, 2017

Published: September 5, 2017

Copyright $\odot 2017$ by authors and Scientific Research Publishing Inc. This work is licensed under the Creative Commons Attribution International License (CC BY 4.0).

http://creativecommons.org/licenses/by/4.0/

\begin{abstract}
This study evaluated the different expressions of cherry tomato growth, yield and quality under bamboo and rice husk biochar applications to soil. The experiment was conducted under glasshouse conditions at Hakozaki campus, Kyushu University, Japan and consisted of 5 treatments, namely 1) no biochar application as a control; 2) $2 \%(\mathrm{RH} 2)$ and 3) $5 \%$ (RH5) of rice husk biochar; 4) $2 \%$ (BB2) and 5) $5 \%$ (BB5) of bamboo biochar. Bamboo biochar application significantly improved tomato growth, including number of leaves, fresh biomass yield of aboveground and underground parts for BB5; number of fruit; fresh yield from $24 \%-25 \%$ for BB2 and BB5. In particular, both bamboo and rice husk biochar application at two rates $2 \%$ and $5 \%$ had positive effects on tomato quality, demonstrated by the increased total sugar content from $56 \%$ to $91 \%$, and the enhancement of ascorbic acid content for BB2 and RH2 by $12 \%$ and $17 \%$, respectively. Those improvements reflected the soil physiochemical property changes after biochar application, including the increase in plant available water for bamboo biochar amendment before and after cultivating by $25 \%-38 \%$ and $9 \%-18 \%$, respectively, compared with those of control; and the increased total soil $\mathrm{N}$ for bamboo biochar treatments (11\% $14 \%)$. Generally, all data above support bamboo biochar utilization for the purpose of improving soil properties and developing crop production.
\end{abstract}

\section{Keywords}

Bamboo, Rice Husk, Soil Available Water, Soil N, Tomato 


\section{Introduction}

Biochar, is produced when biomass is heated in a closed container with little or no available air [1]. Its utilization in large scale in agriculture is expected to improve soil properties, as well as reduce greenhouse gas emissions such as carbon dioxide gas and methane gas [2] [3] [4] [5].

Biochar types vary depending on the raw material, pyrolysis time and temperature [6]. Rice and bamboo are two typical crops in Asia Pacific region. While rice is the most important food crop and 90 percent of world's rice is produced and consumed in this region [7], bamboo is a major non-wood forest and wood substitute found in all regions of the world [8]. Rice husk is one product of rice production. It is the outermost layer of rice seed and it counts for around $20 \%$ of total rice production, equivalent to 154 million tons produced annually in Asian countries [9]. The problem here is to manage the rice husk production effectively not only for economic reasons but also to prevent the environmental pollution from burning it. Similarly to rice husk, bamboo area covers over 6.3 million $\mathrm{km}^{2}$ in Asian countries [10]. It is known as an easy-growing plant and more than ten million farmers are involved with bamboo production, adding up to 35 million jobs [11] [12]. The rapid growth of bamboo forest tends to overpower other plant species and become a monoculture forest, contributing to the loss of biodiversity, soil nutrition, and damaging soil's physical structure [11] [13]. Using rice husk and bamboo as biochar raw materials seems to be a good solution that not only helps to solve those environmental problems mentioned above, but also effectively uses the available material in Asia countries.

The tomato, one of the most popular vegetables grown in home gardens, requires little space for a large yield. It is relatively low in calories and is a good source of vitamins $\mathrm{C}$ and $\mathrm{A}$ that are loaded with many human health benefits. Among various tomato varieties, draft cherry tomato is a small sized one, with its fruits often used in salads. It is easy to grow even in pot conditions, is quite resistant to pests and diseases, and does not require staking.

Many previous papers have evaluated the effect of biochar on the physical and chemical properties as well as soil microorganisms [14]-[21] in terms of soil $\mathrm{pH}$, bulk density, porosity, water retention, saturated hydraulic conductivity, available water content, nutrient absorption and release of nitrogen, phosphorus, potassium and the microorganisms into the soil. There are also numerous papers that identify the impact of biochar on growth, yield, and quality on crops such as rice, maize, soybean, pepper, etc. [22] [23] [24] [25]. However, there were few papers that compared the effect of rice husk and bamboo biochar, two available materials in Asian regions.

This study aimed to clarify the different expressions of draft cherry tomato growth, yield and especially quality under the effects of bamboo and rice husk biochar via exploring the soil physicochemical property changes occurring after biochar application after tomato cultivation, to get a firsthand account of whether bamboo biochar or rice husk biochar utilization was better. 


\section{Material and Methods}

\subsection{Biochar, Soil and Compost Utilization}

Two types of biochar were used in this experiment, namely commercial rice husk biochar $(\mathrm{RH})$ and Bamboo biochar that was pyrolysed at $500^{\circ} \mathrm{C}$ for 1 hour (Figure 1). Biochar was crushed to $\leq 2 \mathrm{~mm}$ before being mixed with soil.

Soil was collected from the soil surface layer (up to $20 \mathrm{~cm}$ depth) from the field at Kyushu University Farm in Kasua-machi, Fukuoka, Japan. The soil was clay loamy, which contains $34 \%$ sand, $30 \%$ silt, and $36 \%$ clay. The soil was air dried and passed through a 2-mm stainless steel mesh sieve.

Biochar, soil $\mathrm{pH}$, and electrical conductivity (EC) were measured by $\mathrm{pH}$ meter (HORIBA LAQUAtwin B-712) and a conductivity meter (HORIBA LAQUAtwin B-771) with 1:10 (w/v) suspension of biochar on deionized water. Bulk density of soil and biochar was calculated by the dry weight of soil and compact weight of biochar in $100 \mathrm{~cm}^{3}$ steel cylinder. The concentration of elemental $\mathrm{C}, \mathrm{H}, \mathrm{N}$ were examined using an elemental analyzer.

Compost used in this experiment was the fermentation type consisting of mixed bark with sludge; manure of chicken, cow and pig; and plant residue. It was produced by the Dainichi Giken Company, registration number 83201. Compost was mixed with soil at the rate 1:5 (weight/weight).

\subsection{Experimental Setup}

The experiment was set up at a glasshouse in Kaizuka field, Hakozaki campus, Kyushu University $\left(33^{\circ} 37^{\prime} 37.8^{\prime \prime} \mathrm{N} ; 130^{\circ} 25^{\prime} 31.3^{\prime \prime} \mathrm{E}\right)$. The two types of biochar were added to the pots at rates of $2 \%$ and $5 \%$ (biochar weight/soil weight). Hereafter the treatments will be named $\mathrm{RH} 2, \mathrm{RH} 5, \mathrm{BB} 2, \mathrm{BB} 5$; totalling 5 treatments in the experiment when counting the control without biochar amendment. Each treat-

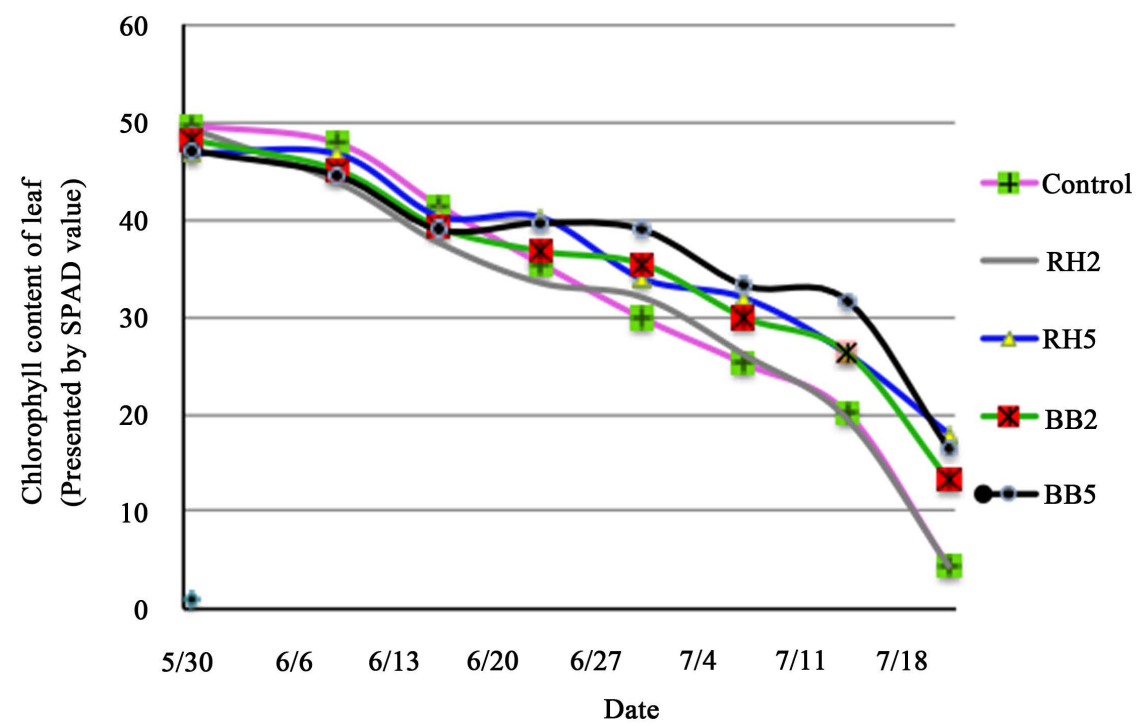

Figure 1. The chlorophyll content of leaf during 7 harvesting weeks. 
ment was repeated 3 times and arranged in a randomized block design. Thus, there were 15 pots in this experiment. The pots were sized $12.5 \mathrm{~cm} \times 18 \mathrm{~cm} \times 20$ $\mathrm{cm}$ (bottom $\times$ top $\times$ height) and filled by soil and biochar mixture to a height of $17 \mathrm{~cm}$. Tomato (1 plant/pot) was sowed in on 15th March 2016, transplanted in a pot on the 20th April 2016, and harvested the 25th July. Seven grams of N: P: K (14:14:14) was added to each pot of tomato. The same irrigation was supplied among treatments. Some crop's growth, yield and quality parameters including crop height $(\mathrm{cm})$; biomass yield $(\mathrm{g})$; number of fruit; fruit diameter $(\mathrm{cm})$; fresh fruit weight $(\mathrm{g})$; total glucose and fructose content $(\mathrm{g} / \mathrm{l})$; ascorbic acid content; and soil physicochemical properties including available water; total $\mathrm{N}, \mathrm{P}, \mathrm{K}$ were observed.

\subsection{Plant and Soil Analysis}

Chlorophyll content of leaf was measured by SPAD 502 Plus meter (A product of KONICA MINOLTA) in the morning at 9:00 am. The height of tomato at harvest time was measured by the length in $\mathrm{cm}$ from the soil surface to the top of crop; Number of leaf: total leaves that crop had during its life; The aboveground and underground fresh biomass yield were observed after harvesting; Fruit diameter $(\mathrm{cm})$ was measured by caliper with the accuracy of $1 / 20 \mathrm{~mm}$; Fresh yield (gram): the total fruit weight of all harvest times, tomatoes were harvested at red stage of the ripening color chart [26]; tomatoes were stored in frozen conditions after harvest. Tomatoes from all harvest times then were extracted to analyze the quality. Total sugar and ascorbic acid contents were measured by RQflex plus 10 meter using test strips base on the procedure number 116,136 and 116,981, respectively, [27] [28]. For total sugar analysis, the extract solid sample was diluted 10 times, then the mixture of $10 \mathrm{ml}$ distilled water, 5 drops of reagent TS- 1 and 1 $\mathrm{ml}$ of pretreated sample was measured by RQflex plus 10 meter.

Soil available water was measured by hanging column and centrifuge methods; soil total N, P, K were determined after wet digestion with salicylic-sulfuric acids and sodium thiosulphate. Then, total $\mathrm{N}$ analysis and total $\mathrm{P}$ were measured by Gilford $300 \mathrm{~N}$ spectrophotometer at wavelength $625 \mathrm{~nm}$ and 710 $\mathrm{nm}$, respectively; Total $\mathrm{K}$ was identified by using Polarized atomic absorption spectrophotometer.

\subsection{Statistical Analysis}

The statistical differences among the treatments were clarified by analysis of variance (ANOVA) in combination with Fisher's least significant difference (LSD) test. The difference among the value was considered statistically significant at $p$ $<0.05$. Data analysis was performed using SPSS 20.0 software.

\section{Results and Discussion}

\subsection{The Soil, Biochar and Compost Information}

Physicochemical properties of soil biochar and compost are listed in Table 1 
Table 1. Data on soil, biochar, and compost used in the experiment.

\begin{tabular}{ccccc}
\hline Parameters & Soil & $\begin{array}{c}\text { Rice husk } \\
\text { biochar }\end{array}$ & $\begin{array}{c}\text { Bamboo } \\
\text { biochar }\end{array}$ & Compost \\
\hline $\mathrm{pH}\left(\mathrm{H}_{2} \mathrm{O}\right)$ & 6.4 & 9.6 & 9.1 & 6.0 \\
Electrical Conductivity $(1: 10 \mathrm{mS} / \mathrm{cm})$ & 0.16 & 0.94 & 0.25 & 0.32 \\
Bulk density $\left(\mathrm{g} / \mathrm{cm}^{3}\right)$ & 1.23 & 0.30 & 0.37 & 0.45 \\
$\mathrm{C} \%$ & 2.25 & 44.81 & 75.78 & 33.73 \\
$\mathrm{H} \%$ & 0.98 & 1.54 & 3.44 & 4.21 \\
$\mathrm{~N} \%$ & 0.18 & 0.43 & 0.35 & 2.47 \\
$\mathrm{C} / \mathrm{N}$ & 12.50 & 104.21 & 216.51 & 13.65 \\
$\mathrm{P} \%$ & 0.27 & 0.23 & 0.26 & 2.00 \\
$\mathrm{~K} \%$ & 0.63 & 0.71 & 0.65 & 2.23 \\
\hline
\end{tabular}

above. The soil $\mathrm{pH}, \mathrm{C} \%, \mathrm{C} / \mathrm{N}$ ratio showed the lower values than those of rice husk and bamboo biochar, while the bulk density of soil was much higher than that of all biochar types and compost. Comparing the carbon (C) percentage of biochar types, Bamboo had more $\mathrm{C}$ content than that of rice husk. This evaluation would be valuable for environmentally sustainable biochar selection, with bamboo forest area expanding to unmanageable levels, and carbon dioxide gas emissions increasing as well. The $\mathrm{pH}, \mathrm{C} / \mathrm{N}$ ratio of compost was the same as those of soil, while its bulk density was similar as that of biochar.

\subsection{Meteorological Data at the Experiment Site}

Whereas crops grown outside would be affected by all weather conditions such as temperature, rainfall, wind velocity, sunlight; crops grown in a glasshouse which was not able to keep the cultivate environment consistent, would be mostly impacted by temperature and sunlight.

The weather data in Table 2 showed that the average temperature in April and May of 2016 was much higher and the sunlight time in April is much lower than those of 40 years averages, since biochar impacts on tomato in this experiment might not be present for the average climate condition.

\subsection{The Response of Biochar Application to Tomato Growth, Yield and Quality}

The effect of biochar on tomato's growth varied according to biochar types and biochar rates. In Figure 1, the leaf chlorophyll content of all treatments during 7 weeks of harvesting showed that biochar amendment (except RH2) enabled plants to maintain the leaf chlorophyll content better than that of control, since it resulted in better keeping photosynthetic activity of plant to final harvest time. It was one important factor to conserve tomato yield and quality during all harvest time. Caliman et al., 2010 also found the same result for better tomato quality growing in a field than in a protected environment [30]. In additional, 
Table 2. The effect of temperature and sunlight time on tomato during cultivation.

\begin{tabular}{ccccccc}
\hline & \multicolumn{3}{c}{ Temperature } & \multicolumn{3}{c}{ Sunlight time hourly } \\
\cline { 2 - 7 } Month in year & $\begin{array}{c}\text { Average } \\
\left({ }^{\circ} \mathrm{C}\right)\end{array}$ & $\begin{array}{c}\text { Difference } \\
\text { with 40 years } \\
\text { average }\left({ }^{\circ} \mathrm{C}\right)\end{array}$ & $\begin{array}{c}\text { Average } \\
\text { temperature } \\
\text { class }\end{array}$ & $\begin{array}{c}\text { Comparing } \\
\text { Average } \\
\text { with 40 years } \\
\text { average }(\%)\end{array}$ & $\begin{array}{c}\text { Sunlight } \\
\text { time } \\
\text { class }\end{array}$ \\
\hline April in 2016 & 16.8 & +1.7 & 2 & 160.2 & 82 & -2 \\
May in 2016 & 20.8 & +1.3 & 2 & 224.9 & 110 & 1 \\
June in 2016 & 23.3 & +0.5 & 1 & 137.7 & 79 & -1 \\
July in 2016 & 28.3 & +0.9 & 1 & 230.0 & 119 & 1 \\
\hline
\end{tabular}

Explanation of class [29]. -2: Fairly low (low); -1: Low(low); 0: Average on average; 1: High(much); 2: Fairly high(much).

Agegnehu et al., 2015 emphasized the close relationship of the higher leaf chlorophyll content under biochar application with the more advanced crop growth stage [31].

Figure 2 clarified the effect of biochar on tomato plant height, number of leaves and biomass yield. Applied bamboo biochar led to significantly increase tomato leaf numbers, fresh biomass yield in above and underground parts for BB5 by $21 \%, 40 \%$ and $114 \%$, respectively. However, tomato's growth characters in rice husk biochar treatments did not show any significant difference, or was even slightly reduced compared with those of control.

Bamboo biochar also showed positive impacts on number of fruit (NF) and fresh yield (FY) (Figure 3). Whereas two rice husk biochar applications (RH2\%, RH5\%) did not have any significant impact on NF, FD and FY. Bamboo biochar showed a significant increase for both NF and FY at both rates $2 \%$ and $5 \%$. In detail, the increasing values for NF were from 10.7 fruits (BB2) to 12.7 fruits (BB5), and for FY were from 23.2 gram/crop (BB5) to 24.7 gram/crop (BB2). The fruit diameter was the same among treatments from $1.73-1.80 \mathrm{~cm}$. The positive impact results of bamboo biochar amendment was also found by Carnaje et al. (2015) [32], who reported the increase in mung bean production by $27 \%$ in height, $8.5 \%-15.7 \%$ for root nodules and up to $102 \%$ of pods in acidic soil; Brassica grown on mine-polluted soil in Feng county (FC) and Tongguan (TG) of China showed the improving of shoot/root growth, dry biomass and in increment of chlorophyll together with carotenoid concentration [33].

Because cherry tomato is usually used as a fresh vegetable in human daily meals, its quality was a very important character that the authors wanted to emphasize in this experiment. From Figure 4, both bamboo and rice husk biochars at each application rate had positive impacts on tomato's total sugar content (glucose and fructose) by 55\% - 91\%. In addition, bamboo and rice husk biochars applied at $2 \%$ significantly increased total ascorbic acid content compared with that of control (12\% - 17\%), while this trend was not found for the $5 \%$ biochar application. The response of biochar application to the crop's quality had not been mentioned much in previous studies. Research of Iowa State University showed that, there was no significant difference of total soluble solids (Brix ${ }^{\circ}$ 


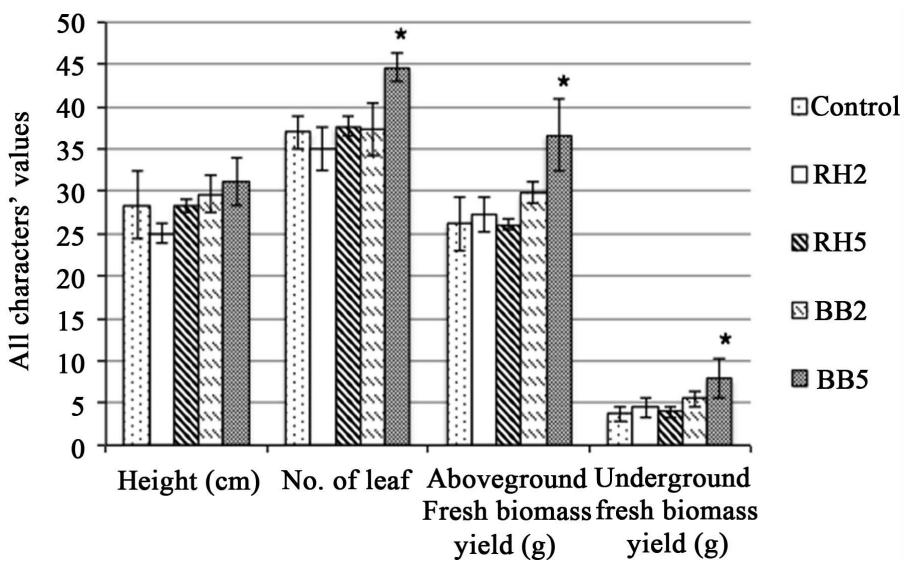

Figure 2. Some growth characters of tomato in the experiment. Character $\left(^{*}\right)$ shows the significant difference comparing with control at $\mathrm{p}$ value $p<0.05$. Mean \pm S.E.M $=$ Mean values \pm Standard error of means.

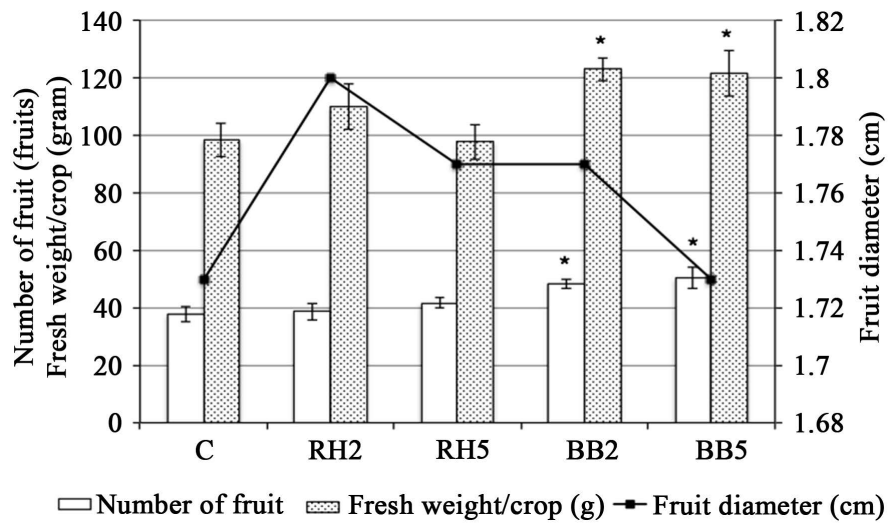

Figure 3. The tomato yield's characters. Character $\left(^{*}\right)$ shows the significant difference comparing with control at $\mathrm{p}$ value $p<0.05$. Mean \pm S.E.M $=$ Mean values \pm Standard error of mean.

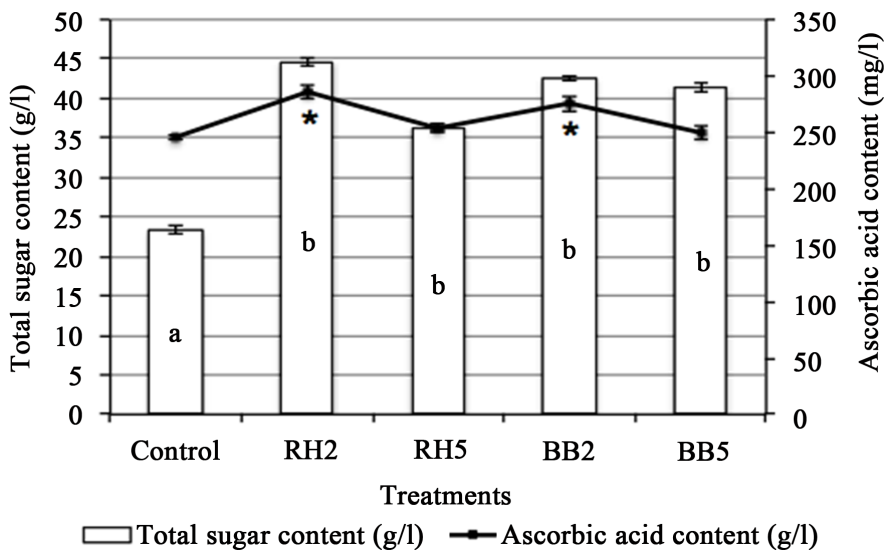

Figure 4. The tomato quality's characters. Character $\left({ }^{*}\right)$ shows the significant difference comparing with control at $\mathrm{p}$ value $p<0.05$. Different small alphabet characters show the statically significant difference compared with control. Mean \pm S.E.M $=$ Mean values \pm Standard error of mean. 
value) for sweet-corn or carrot in condition of biochar application compared with that of control [34] [35]; whereas under deficit irrigation or partial root zone dry irrigation conditions, biochar application contributed to an increase in the quality of tomato compared with the non-biochar control [3]. Comparing the tomato quality cultivated in three different biochar applications, Petruccelli et al., 2015 found that total phenol and flavonoid contents, as well as antioxidant activity, were higher in fruits grown in substrate amended with straw biochar and olive residue biochar [36].

\subsection{The Changes in Soil after Biochar Application}

Plant survival and growth is critically influenced by soil available water and nutrients. Biochar application improved physical properties of the soil and changed the nutritional dynamic. However, its impacts depended on soil type, biochar raw material, biochar rate, and biochar production method including pyrolysis temperature and time [37].

In this experiment, bamboo biochar amendment to soil mixture played a better role in terms of holding much more available water and nitrogen than rice husk biochar, for reasons possibly relating to its own physicochemical properties such as its absorption capacity. Some studies on physical properties of bamboo and rice husk biochars showed that bamboo biochar (BB) had much higher BET surface area than that of rice husk biochar (RH), such as $434.53 \mathrm{~m}^{2} / \mathrm{g}$ or $169 \mathrm{~m}^{2} / \mathrm{g}$ for BB compared with $3.29 \mathrm{~m}^{2} / \mathrm{g}$ or $12.2 \mathrm{~m}^{2} / \mathrm{g}$ for RH [38] [39]. This resulted in better physisorption inside the pores and on the inner surface of $\mathrm{BB}$ than that of $\mathrm{RH}$ [37]. This hypothesis would be improved by the data of soil available water and soil NPK in the comparison between bamboo biochar and rice husk biochar application.

Biochar amendment helped to increase soil water holding capacity. This ability was found by many studies such as Brantly et al. (2015) for poultry litter and woodchip biochar application to loam soil [40]; Burrell et al. (2016) for straw biochar amendment to Planosol soil type [41], Aslam et al. (2014) emphasized that soil water holding capacity increased by biochar amendment, but it varied with respect to soil texture and biochar rate [42]. In this study, bamboo biochar significantly increased available water, which was recorded before and after tomato cultivation by $25 \%-38 \%$ and $9 \%-18 \%$, respectively. This trend was not found for rice husk biochar at either time of analysis, however the more water availability in bamboo biochar treatments recorded, the more advanced crop growth was indicated in this experiment, because of the importance of water plays in the crop's life [43] (Figure 5).

The soil analytical results after harvesting (Table 3) indicated that biochar application significantly increased soil C, especially for bamboo biochar. Each bamboo biochar application rate $2 \%$ or $5 \%$ also clarified the significant positive impacts of on soil total $\mathrm{N}$ by $18 \%$ or $14 \%$ increasing, respectively, compared with that of control. The $\mathrm{N}$ dynamic in soil with biochar amendment was affected by 


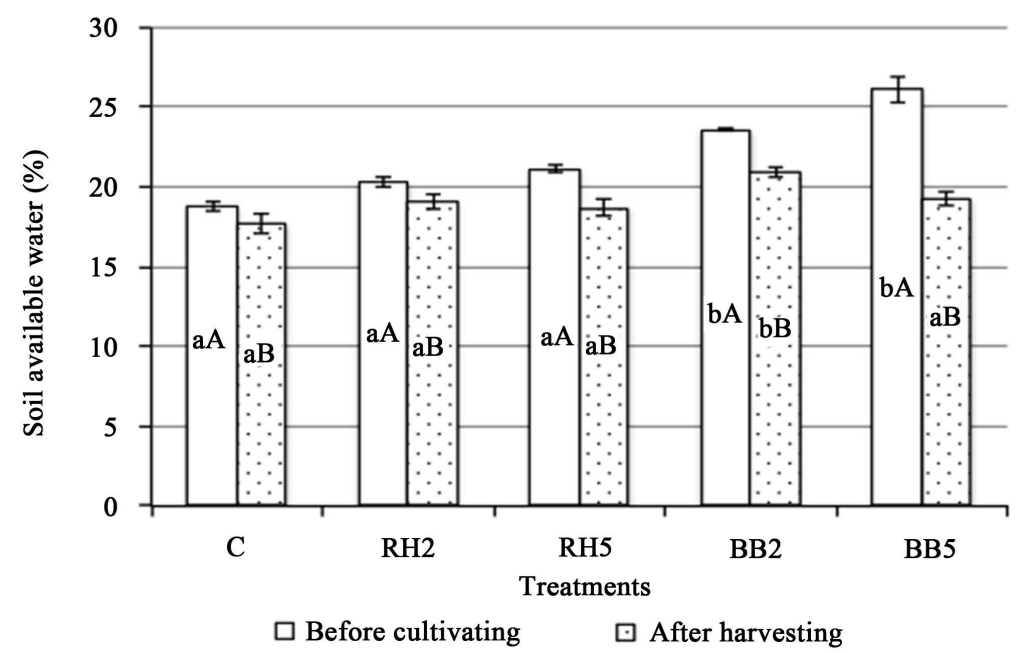

Figure 5. Water availability by treatment. The lower case letters indicate the differences between control and biochar treatments and capital case letters indicate the differences before cultivating and after harvesting $(p<0.05)$ by Fisher's LSD test.

Table 3. Effect of rice husk and bamboo biochar on soil chemical properties after harvesting.

\begin{tabular}{ccccc}
\hline Treatment & Total C (\%) & Total N (\%) & Total P (\%) & Total K (\%) \\
\hline Control & $2.84 \mathrm{a}$ & $0.22 \mathrm{a}$ & $0.32 \mathrm{ab}$ & $0.71 \mathrm{a}$ \\
RH2 & $4.06 \mathrm{a}$ & $0.21 \mathrm{a}$ & $0.32 \mathrm{ab}$ & $0.70 \mathrm{a}$ \\
RH5 & $4.39 \mathrm{a}$ & $0.22 \mathrm{a}$ & $0.31 \mathrm{~b}$ & $0.71 \mathrm{a}$ \\
BB2 & $7.63 \mathrm{~b}$ & $0.26 \mathrm{~b}$ & $0.33 \mathrm{ac}$ & $0.71 \mathrm{a}$ \\
BB5 & $8.42 \mathrm{~b}$ & $0.25 \mathrm{~b}$ & $0.34 \mathrm{c}$ & $0.72 \mathrm{a}$ \\
LSD5\% & $\mathbf{2 . 3 1}$ & $\mathbf{0 . 0 2}$ & $\mathbf{0 . 0 2}$ & $\mathbf{0 . 0 5}$ \\
\hline
\end{tabular}

Different letter shows the significant different among values.

complex processes including absorption, leaching, $\mathrm{N}$ mineralization, nitrification and $\mathrm{N}$ immobilization [31] [44]. Biochar application often immobilizes soil mineral $\mathrm{N}$ because of input of label $\mathrm{C}$, and increasing soil $\mathrm{C} / \mathrm{N}$ ratio [45] or fixes $\mathrm{N}$ through absorption [37]. However, due to the amount of $\mathrm{N}$ added and low $\mathrm{C} / \mathrm{N}$ ratio of the soil which would limit $\mathrm{N}$ immobilization [31]; additionally, biochar amendment developed as a slow release $\mathrm{N}$ fertilizer [46], meaning biochar might have a positive impact on soil $\mathrm{N}$ in this experiment. Table 3 showed the total $\mathrm{N}$ of bamboo biochar treatments was significantly higher than that of control or rice husk biochar, which may be a result of (1) the effectively reduced $\mathrm{N}$ leaching of biochar amendment, and/or (2) the higher physicsorption capacity of bamboo biochar because of higher BET surface area compared with rice husk biochar [37] [47].

Phosphorus in soil, next to nitrogen, is often the most limiting nutrient for crop production. Biochar application can change the $\mathrm{P}$ dynamic in soil. Parvage et al., 2013 indicated that "wheat residue char can act as a source of soluble P" 
[48], however "biochar acted as a sink instead of a source of $\mathrm{P}$ when applied at high quantity ( $2 \%-4 \%$ of soil weight for $0-10 \mathrm{~cm})$ ". It was also found [49] that the application of fast pyrolysis of corn stover (Zea mays L.), Ponderosa pine wood residue, and switchgrass biochars had different effects to acidic soil and calcareous soil, finding that "the incorporation of biochars to acidic soil at 40 $\mathrm{g} / \mathrm{kg}(4 \%)$ increased the equilibrium solution P concentration (reduced the sorption) and increased available sorbed P. In calcareous soil, application of alkaline biochars (corn stover and switchgrass biochars) significantly increased the sorption of $\mathrm{P}$ and decreased the availability of sorbed P.”. A meta-analysis of biochar effects on plant productivity and nutrient cycling identified that the application of biochar to soils resulted in increased aboveground productivity $(P<0.01)$, and soil $P(P<0.001)$ [50]. In addition, when biochar is applied together with compost, it provides a slow-release $P$ pool for plants [31] [51] [52] thus enhancing crop productivity for a long term period. In this study, BB5 showed a statically significant increase in the total P compared with rice husk biochar and control. This result might come from the higher BET surface area of bamboo char than that of rice husk char [47].

The potassium dynamics in soil are changed by biochar amendment in several ways. Firstly, it reduces the leaching losses [53]. Secondly, it allows for the nutrient retention, including $\mathrm{K}$ [54] because biochar has porous structure, large surface area and negative surface charge [55] [56] [57] [58]. The meta-analysis of biochar effects on nutrient cycling base on 371 independent experiments also emphasized that soil $\mathrm{K}$ was increased by biochar application at $P<0.001$ [50]. No change in soil total $\mathrm{K}$ was found in this experiment, so this state could be explained by the $\mathrm{K}$ content in the compost that we used.

\section{Conclusion}

Our results indicated that between bamboo and rice husk biochar applications to soil-compost mixture, only bamboo biochar showed positive effects on tomato growth and yield. The significant increase of tomato growth and yield compared with control was showed by BB5 in enhancement of leaf number and biomass yield. The BB2 and BB5 showed increased fruit number from $28 \%$ to $34 \%$, while that of RH was $4 \%$ for RH2 and $11 \%$ RH5. Those enhancements therefore contributed to enhanced tomato yield from $23 \%$ (BB5) to $25 \%$ (BB5). The different tomato expressions in growth and yield of two biochar types application reflected the better ability of bamboo biochar to store water and nutrient compared with rice husk char. Furthermore, biochar application for both rice husk and bamboo materials help to significantly improve the tomato quality including total sugar content for all biochar treatments and ascorbic acid content for BB2 and $\mathrm{RH} 2$.

\section{Acknowledgements}

The authors would like to acknowledge Associate Professor Takeo YAMAKAWA 
and Mr. Kyi Moe from Biophysical Chemistry Laboratory, Agriculture Faculty of Kyushu University for allowing and guiding us in analyzing soil chemical properties. We would also like to thank Mr. Dang Duc Viet who supplied us bamboo biochar material for experiment, and the reviewers for their valuable comments which have enriched the quality of the manuscript.

\section{References}

[1] Lehmann, J. and Stephen, J. (2009) Biochar for Environmental Management, Vol. 1. Routledge, Abingdon-on-Thames.

[2] Woolf, D., Amonette, J.E., Street-Perrott, F.A., Lehmann, J. and Joseph, S. (2010) Climate Change. Nature Communications, 1, 1-9. https://doi.org/10.1038/ncomms1053

[3] Akhtar, S.S., Li, G., Andersen, M.N. and Liu, F. (2014) Biochar Enhances Yield and Quality of Tomato under Reduced Irrigation. Agricultural Water Management, 138, 37-44. https://doi.org/10.1016/j.agwat.2014.02.016

[4] Sean, D.S.R., Case, D.C. and Mcnamara, N.P. (2014) Can Biochar Reduce Soil Greenhouse Gas Emissions from a Miscanthus Bioenergy Crop? Global Change Biology, 6, 76-89. https://doi.org/10.1111/gcbb.12052

[5] Simon Shackley, D.M., Sohi, S. and Haszeldine, A. (2009) Biochar, Reducing and Removing $\mathrm{CO}_{2}$ While Improving Soils: A Significant and Sustainable Response to Climate Change.

[6] Zheng, W., Sharma, B.K. and Rajagopalan, N. (2010) Using Biochar as a Soil Amendment for Sustainable Agriculture. Illinois Department of Agriculture, 7276.

[7] FAO (2000) Bridging the Rice Yield Gap in the Asia-Pacific Region. FAO, Rome.

[8] FAO (2005) World Bamboo Bamboo Resources Products. FAO, Rome.

[9] Santiaguel, A.F. (2013) A Second Life for Rice Husk. In: Rice Today, Vol. 12, No. 2, IRRI, Rice Science for Food Securitythrough Smallholder and Agri-business Development in Africa, The 3rd Africa Rice Congress 2013, Africa Rice, Cameroon, 12-13.

[10] Bystriakova, C.M.A.S.N., Kapos, V. and Lysenko, I. (2014) Distribution and Conversation Status of Forest Bamboo Biodiversity in the Asia-Pacific Region. CEUR Workshop Proceedings, 1225, 41-42.

[11] Buckingham, K., Jepson, P., Wu, L., Rao, I.V.R., Jiang, S., Liese, W., Lou, Y. and Fu, M. (2011) The Potential of Bamboo is Constrained by Outmoded Policy Frames. Ambio, 40, 544-548. https://doi.org/10.1007/s13280-011-0138-4

[12] Hogarth, N.J. and Belcher, B. (2013) The Contribution of Bamboo to Household Income and Rural Livelihoods in a Poor and Mountainous County in Guangxi, China. International Forestry Review, 15, 71-81. https://doi.org/10.1505/146554813805927237

[13] Song, X., Zhou, G., Jiang, H., Yu, S., Fu, J. and Li, W. (2011) Carbon Sequestration by Chinese Bamboo Forests and Their Ecological Benefits : Assessment of Potential, Problems , and Future Challenges. Environmental Reviews, 19, 418-428. https://doi.org/10.1139/a11-015

[14] Glaser, B., Lehmann, J. and Zech, W. (2002) Ameliorating Physical and Chemical Properties of Highly Weathered Soils in the Tropics with Charcoal-A Review. Biology and Fertility of Soils, 35, 219-230. 
https://doi.org/10.1007/s00374-002-0466-4

[15] Herath, H.M.S.K., Camps-Arbestain, M. and Hedley, M. (2013) Effect of Biochar on Soil Physical Properties in Two Contrasting Soils: An Alfisol and an Andisol. Geoderma, 209-210, 188-197. https://doi.org/10.1016/j.geoderma.2013.06.016

[16] Wahabu, S., Fosu-Mensah, B.Y. and Nyame, F.K. (2015) Impact of Charcoal Production on Physical and Chemical Properties of Soil in the Central Gonja District of the Northern Region, Ghana. Cannadian Center of Science and Education, 5, 11-18. https://doi.org/10.5539/enrr.v5n3p11

[17] Jayathunga, C. (2016) Woodchip Biochar with or without Synthetic Fertilizers Affects Soil Properties and Available Phosphorus in Two Alkaline, Chernozemic Soils. Canadian Journal of Soil Science, 96, 472-484.

https://doi.org/10.1139/cjss-2015-0094

[18] Diamadopoulos, E. (2016) The Impact of Biochars Prepared from Agricultural Residues on Phosphorus Release and Availability in Two Fertile Soils. Journal of Environmental Management, 181, 536-543.

https://doi.org/10.1016/j.jenvman.2016.07.012

[19] Molnár, M., Vaszita, E., Farkas, É., Ujaczki, É., Fekete-Kertész, I. and Tolner, M. (2016) Science of the Total Environment Acidic Sandy Soil Improvement with Biochar-A Microcosm Study. Science of the Total Environment, 563-564, 855-865. https://doi.org/10.1016/j.scitotenv.2016.01.091

[20] Milla, O.V., Rivera, E.B., Huang, W.-J. And Chien, C. C. (2013) Agronomic Properties and Characterization of Rice Husk and Wood Biochars and Their Effect on the Growth of Water Spinach in a Field Test. Journal of Plant Nutrition and Soil Science, 13, 251-266.

[21] Pandian, K., Subramaniayan, P., Gnasekaran, P. and Chitraputhirapillai, S. (2016) Effect of Biochar Amendment on Soil Physical, Chemical and Biological Properties and Groundnut Yield in Rainfed Alfisol of Semi-Arid Tropics. Archives of Agronomy and Soil Science, 62. https://doi.org/10.1080/03650340.2016.1139086

[22] Zhu, Q.H., Peng, X.H., Huang, T.Q., Xie, Z.B. and Holden, N.M. (2014) Effect of Biochar Addition on Maize Growth and Nitrogen Use Efficiency in Acidic Red Soils. Pedosphere, 24, 699-708. https://doi.org/10.1016/S1002-0160(14)60057-6

[23] Kang, S.-W., Park, J.-W., Seo, D.-C., Ok, Y.S., Park, K.-D., Choi, I.-W. and Cho, J.-S. (2016) Effect of Biochar Application on Rice Yield and Greenhouse Gas Emission under Different Nutrient Conditions from Paddy Soil. Journal of Environmental Engineering, 142, 1-7. https://doi.org/10.1061/(ASCE)EE.1943-7870.0001083

[24] Yilangai, R., Manu, S., Pineau, W., Mailumo, S. and Okeke-Agulu, K. (2014) The Effect of Biochar and Crop Veil on Growth and Yield of Tomato (Lycopersicum esculentus Mill) in Jos, North Central Nigeria. Current Agriculture Research Journal, 2, 37-42. https://doi.org/10.12944/CARJ.2.1.05

[25] Graber, E.R., Harel, Y.M., Kolton, M., Cytryn, E., Silber, A., David, D.R., Tsechansky, L., Borenshtein, M. and Elad, Y. (2010) Biochar Impact on Development and Productivity of Pepper and Tomato Grown in Fertigated Soilless Media. Plant Soil, 337, 481-496. https://doi.org/10.1007/s11104-010-0544-6

[26] USDA (1975) Usda-Tomato-Ripeness-Color-Chart. https://ucanr.edu/repository/view.cfm?article=83755\%20\&groupid=9

[27] Total Sugar Test. 
http://www.merckmillipore.com/JP/ja/product/Test-Azúcar-total-(glucosa-y-fructo sa),MDA_CHEM-116136\#anchor_PI

[28] Ascorbic Acid Test. http://www.merckmillipore.com/JP/ja/product/Test-Ácido-ascórbico,MDA_CHEM -116981\#anchor_PI

[29] Japan Meteorological Agency. http://www.data.jma.go.jp/gmd/cpd/cgi-bin/view/hist.php?reg_no=31\&year=2016\& month $=0$ \&kind $=2$

[30] Caliman, F.R.B., da Silva, D.J.H., Cezar, P., Fontes, R., Moreira, G.R. and Mantovani, E.C. (2010) Quality of Tomatoes Grown under A Protected Environment and Field Conditions. Idesia (Chile), 28, 75-82.

[31] Agegnehu, G., Bass, A.M., Nelson, P.N., Muirhead, B., Wright, G. and Bird, M.I. (2015) Agriculture, Ecosystems and Environment Biochar and Biochar-Compost as Soil Amendments: Effects on Peanut Yield, Soil Properties and Greenhouse Gas Emissions in Tropical North. Agriculture, Ecosystems \& Environment, 213, 72-85. https://doi.org/10.1016/j.agee.2015.07.027

[32] Carnaje, N.P. and Malaluan, R.M. (2015) Advances in Environmental SciencesInternational Journal of the Bioflux Society Amending Acidic Soil with Bamboo (Bambusa blumeana) Biochar: Effect on Mung Bean (Vigna radiata) Growth Rate and Yield. AES Bioflux, 7, 109-123.

[33] Ali, A., Guo, D., Zhang, Y., Sun, X., Jiang, S., Guo, Z. and Huang, H. (2017) Using Bamboo Biochar with Compost for the Stabilization and Phytotoxicity Reduction of Heavy Metals in Mine-Contaminated Soils of China. Scientific Reports, 1-12.

[34] Nair, A. and Lawson, V. (2013) Effect of Biochar on Sweet Corn Production. Iowa State Research Farm Progress Reports, Iowa State Research Farm.

[35] Carpenter, B.H. and Nair, A. (2014) Effect of Biochar on Carrot Production. Iowa State Research Farm Progress Reports, Iowa State Research Farm.

[36] Petruccelli, R., Bonnetti, A., Traversi, M.L., Faraloni, C., Valagussa, M. and Pozzi, A. (2015) Influence of Biochar on Nutritional Quality of Tomato. Crop \& Pasture Science, 66, 747-755. https://doi.org/10.1071/CP14247

[37] Nhan, N.T.T., Xu, C., Tahmasbian, I., Che, R., Xu, Z., Zhou, X., Wallace, H.M. and Hosseini, S. (2017) Geoderma Effects of Biochar on Soil Available Inorganic Nitrogen : A Review and Meta-Analysis. Geoderma, 288, 79-96. https://doi.org/10.1016/j.geoderma.2016.11.004

[38] Nguyen, H. (2016) Physicochemical Characterization of Various Vietnamese Biomass Residue-Derived Biochars (Wood, Bamboo and Risk Husk). Geophysical Research, 18, 13305.

[39] Wang, Y., Hu, Y., Zhao, X., Wang, S. and Xing, G. (2013) Comparisons of Biochar Properties from Wood Material and Crop Residues at Different Temperatures and Residence Times. Energy \& Fuels, 27, 5890-5899. https://doi.org/10.1021/ef400972z

[40] Brantley, K.E., Brye, K.R., Savin, M.C. and Longer, D.E. (2015) Biochar Source and Application Rate Effects on Soil Water Retention Determined Using Wetting Curves. Journal of Soil Science, 5, 1-10. https://doi.org/10.4236/ojss.2015.51001

[41] Burrell, L.D., Zehetner, F., Rampazzo, N., Wimmer, B. and Soja, G. (2016) Long-Term Effects of Biochar on Soil Physical Properties. Geoderma, 282, 96-102. https://doi.org/10.1016/j.geoderma.2016.07.019

[42] Aslam, Z., Khalid, M. and Aon, M. (2014) Impact of Biochar on Soil Physical Prop- 
erties. Scholars Journal of Agriculture and Veterinary, 4, 280-284.

[43] Marvin, D. and Ferguson, H. (1959) The Role Of Water in Plant Growth. United States of Golf Association Journal and Turf Management.

[44] Clough, T.J., Condron, L.M., Kammann, C. and Müller, C. (2013) A Review of Biochar and Soil Nitrogen Dynamics. Agronomy, 3, 275-293. https://doi.org/10.3390/agronomy3020275

[45] Ippolito, J., Ippolito, J.A., Laird, D.A. and Busscher, W.J. (2017) Environmental Benefits of Biochar. Journal of Environmental Quality, 41, 967-972.

https://doi.org/10.2134/jeq2012.0151

[46] Clough, T.J., Condron, L.M., Kammann, K. and Muller, C. (2013) A Review of Biochar and Soil Nitrogen Dynamics. Agronomy, 3, 275-293.

https://doi.org/10.3390/agronomy3020275

[47] Van Hien, N., Valsami-Jones, E., Cong, N., Lehmann, J., Joseph, S., Hough, R., Thi, T., Thi, N. and Tam, T. (2013) Physicochemical Characterization of Various Vietnamese Biomass Residue-Derived Biochars (Wood, Rice Husk, and Bamboo). Geophysical Research Abstracts, 18.

[48] Parvage, M.M., Ulén, B., Eriksson, J., Strock, J. and Kirchmann, H. (2013) Phosphorus Availability in Soils Amended with Wheat Residue Char. Biology and Fertility of Soils, 49, 245-250. https://doi.org/10.1007/s00374-012-0746-6

[49] Chintala, R., Schumacher, T.E., McDonald, L.M., Malo, D.D., Papiernik, S.K., Clay, S.A. and Julson, J.L. (2014) Phosphorus Sorption and Availability from Biochars and Soil/Biochar Mixtures. Clean Soil Air Water, 42, 626-634. https://doi.org/10.1002/clen.201300089

[50] Biederman, L.A. and Harpole, W.S. (2013) Biochar and Its Effects on Plant Productivity and Nutrient Cycling: A Meta-Analysis. Global Change Biology, 5, 202-214. https://doi.org/10.1111/gcbb.12037

[51] Slavich, P.G., Sinclair, K. and Morris, S.G. (2013) Contrasting Effects of Manure and Green Waste Biochars on the Properties of an Acidic Ferralsol and Productivity of a Subtropical Pasture. Plant Soil, 366, 213-227. https://doi.org/10.1007/s11104-012-1412-3

[52] Wang, T., Camps-Arbestain, M., Hedley, M. and Bishop, P. (2012) Predicting Phosphorus Bioavailability from High-Ash Biochars. Plant Soil, 357, 173-187. https://doi.org/10.1007/s11104-012-1131-9

[53] Laird, D., Fleming, P., Wang, B., Horton, R. and Karlen, D. (2010) Biochar Impact on Nutrient Leaching from a Midwestern Agricultural Soil. Geoderma, 158, 436442. https://doi.org/10.1016/j.geoderma.2010.05.012

[54] Liang, B., Lehmann, J., Solomon, D., Kinyangi, J., Grossman, J., Skjemstad, J.O., Thies, J., Luiza, F.J., Petersen, J. and Neves, E.G. (2006) Black Carbon Increases Cation Exchange Capacity in Soils. Soil Science Society of America Journal, 70, 1719-1730. https://doi.org/10.2136/sssaj2005.0383

[55] Bird, M.I., Ascough, P.L., Young, I.M., Wood, C.V. and Scott, A.C. (2008) X-Ray Microtomographic Imaging of Charcoal. Journal of Archaeological Science, 35, 2698-2706. https://doi.org/10.1016/j.jas.2008.04.018

[56] Cheng, C., Lehmann, J. and Engelhard, M.H. (2008) Natural Oxidation of Black Carbon in Soils: Changes in Molecular form and Surface Charge along a Climosequence. Geochimica et Cosmochimica Acta, 72, 1598-1610. https://doi.org/10.1016/j.gca.2008.01.010

[57] Downie, A. (2009) Physical Properties of Biochar. In: Biochar for Environmental 
Management, Routledge, Abingdon-on-Thames.

[58] Novak, J.M., Lima, I., Gaskin, J.W., Steiner, C., Das, K.C., Ahmedna, M., Watts, D.W., Warren, J. and Schomberg, H. (2009) Characterization of Designer Biochar Produced at Different Temperatures and Their Effects on a Loamy Sand. Annals of Environmental Science, 3, 195-206.

\section{Scientific Research Publishing}

Submit or recommend next manuscript to SCIRP and we will provide best service for you:

Accepting pre-submission inquiries through Email, Facebook, LinkedIn, Twitter, etc. A wide selection of journals (inclusive of 9 subjects, more than 200 journals)

Providing 24-hour high-quality service

User-friendly online submission system

Fair and swift peer-review system

Efficient typesetting and proofreading procedure

Display of the result of downloads and visits, as well as the number of cited articles Maximum dissemination of your research work

Submit your manuscript at: http://papersubmission.scirp.org/

Or contact as@scirp.org 